\title{
Control of meningococcal meningitis outbreaks in sub-Saharan Africa
}

\author{
Jean-Philippe Chippaux \\ IRD UR010, Team "Mother's and Child's health in tropical environment", Institut de Recherche pour le Développement, La Paz, \\ Bolivia
}

\begin{abstract}
Outbreaks of Neisseria meningitidis recur frequently in the African Sahel where they are responsible for high mortality and morbidity, especially in children. An effective vaccine has been in existence for more than 30 years, but despite this, the control of epidemics has failed. Moreover, the geographical distribution of $N$. meningitidis seems to be increasing, perhaps because of climate change but also because of the economic crisis which prevails throughout much of Africa leading to population movements and the breakdown of essential services. Although alarming, the emergence of new serogroups in recent epidemics (such as serogroups X and W135) should not mask the fact that serogroup A remains the most common meningococcal isolate from meningitis cases and is therefore the most significant target for control. The development of a low-cost conjugate meningococcal vaccine should support a strategy of preventive immunization, as this strategy is one that appears most effective to control this plague.
\end{abstract}

Key Words: epidemics, meningitis, Neisseria meningitidis, Africa, polysaccharides, conjugate vaccine, control strategy

J Infect Developing Countries 2008; 2(5):335-345.

Received 7 March 2008 - Accepted 29 July 2008

Copyright () 2008 Chippaux. This is an open access article distributed under the Creative Commons Attribution License, which permits unrestricted use, distribution, and reproduction in any medium, provided the original work is properly cited.

\section{Introduction}

More than a half of the cases of Neisseria meningitidis meningitis that are noted in the world occur in the African Sahel [1] where, after malaria and diarrhoeal or respiratory disease, it is the most frequent cause of mortality in children under 15 years. Recurring epidemics are a major feature of the epidemiology of this infection, and its significance in communities in the Sahel region is shown by, in some African ethnic groups, greetings that include questions about recent meningitis deaths among children in the family. In recent years changes have been observed in the epidemiology of $N$. meningitidis meningitis [2] with population migration and climatic changes suspected as the causes of the extension of epidemic foci. In addition to these geographic and demographic changes, new serogroups have emerged in the last decade that are involved in both sporadic cases and severe outbreaks, leading to new questions regarding the spread of infection and its control [3].

Following the development of the meningococcal polysaccharide vaccine (MPV), two control strategies for the prevention of meningitis epidemics have been proposed, preventive strategies which include routine immunization or periodic mass campaigns and reactive strategies where immunization is conducted only in response to the occurrence of a confirmed outbreak $[4,5]$. The current development of a low-cost meningococcal conjugate vaccine (MCV) has introduced new arguments to the debate regarding which of these strategies may be the more effective $[3,6]$.

The purpose of this review is to present some of these new issues on meningococcal meningitis epidemics in sub-Saharan Africa and to discuss the methods of management and control.

\section{Bacteriology}

Neisseria meningitidis is an aerobic gram-negative bacterium that is oxidase and catalase positive, and reproduces extra-cellularly. Cells of the genus Neisseria tend to be arranged in pairs, giving a coffee bean appearance. Pathogenic Neisseria are fastidious organisms that are difficult to culture in the laboratory, and isolation and identification usually requires special training and facilities. Unlike some other members of the genus, $N$. meningitidis can be cultivated on regular culture media enriched with blood, though care must be taken to prevent contamination by other bacteria. The capsule that surrounds $N$. meningitidis (figure 1) consists of polysaccharides, the structure of which is used to define the serogroups. Below the capsule there 
is an outer membrane which contains lipopolysaccharides and proteins that define the immunotypes and serotypes. There are 3 main serogroups, A, B and C, of which serogroup A is the most important in the Sahel region. In addition, there are other serogroups such as X and W135, but these remain relatively uncommon. Between the outer and the cytoplasmic membranes, peptidoglycans maintain the bacterial structure and are involved in metabolic exchange. Protein filaments, the pili, extend from the outer membrane through the capsule, and they facilitate the adhesion of the bacterium to the mucous membrane of the oropharynx. While many people in endemic areas may have asymptomatic carriage, in some cases the meningococci are able to enter into the blood-stream, and after passage of organisms in the blood the pili are also important in enabling the bacteria to cross the meningeal barrier and enter the central nervous system.

Figure 1. Structure of Neisseria.

Capsule = serogroups; Outer membrane = lipopolysaccharids (immunotypes and serotypes); Peptidoglycane between the two membranes; Pili $=$ fimbrial proteins (initial binding to epithelial cells).

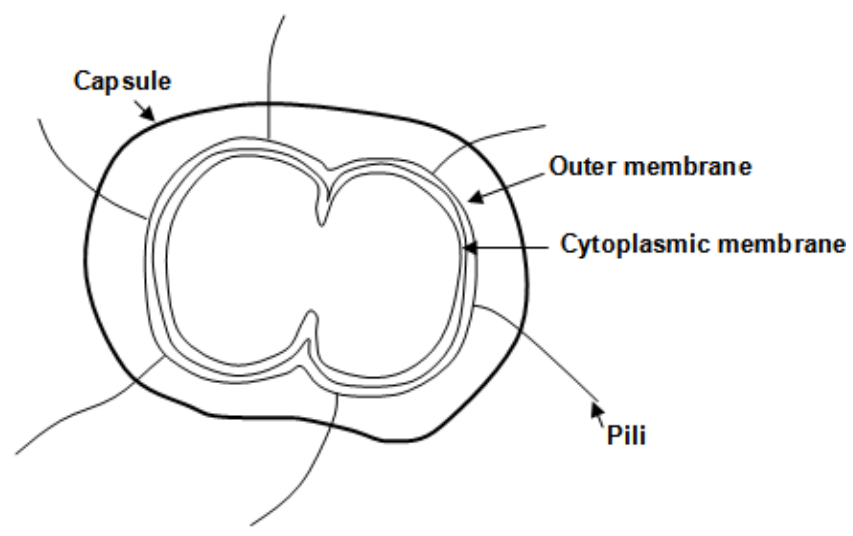

Both capsule polysaccharides and outer membrane proteins are immunogenic and play an important role in virulence, in particular facilitating resistance to phagocytosis and crossing of the meningeal membranes. Because of their importance in virulence, these antigens are good candidate targets for vaccine development. Identification of the serogroups of the bacterium during an outbreak of meningococcal infections is useful both in identifying the epidemiological characteristics of the outbreak and also in defining the most suitable vaccine to use for control. Because of their role in virulence, the morbidity and mortality that occurs in epidemics may also be related to particular serogroups, serotypes or clones. Comparisons of strains isolated from different epidemics and their relationships to disease are, however, difficult to interpret because data from different studies do not have the same reliability, nor the same level of precision.

High mortality is a regular feature at the beginning of an epidemic, before appropriate measures are taken, whatever serogroup may be involved. As epidemics become more stable, mortality rates usually fall, and mortality rates of about $10 \%$ have been commonly reported in more mature epidemics in sub-Saharan Africa [1], a figure that has changed little for several decades despite the advances made in diagnosis, treatment, and prevention. Case fatality rates of up to $50 \%$ have, in some epidemics, been related to specific serogroups, for example the $N$. meningitidis W135 epidemic in the Gambia [7] and in Saudi Arabia [8]. These have usually been limited epidemics with transmission in new geographic regions and so it remains difficult to differentiate whether the high mortality is due to the virulence of the pathogen or the immunologic susceptibility of the host.

The lack of "herd immunity" has been suggested as a reason for the increase of both the incidence and severity of the disease with newly emerging serogroups [7].

\section{Epidemiology}

Neisseria meningitidis is a common inhabitant of the throat of healthy humans, and asymptomatic carriage is a significant factor in the spread of bacteria through a community. The frequency of asymptomatic carriage of $N$. meningitidis is seasonal and occurs in all age groups [9-13]. Five serogroups (A, B, C, Y and $\mathrm{W} 135$ ) are recognized as the groups most commonly associated with meningitis, with serogroup A being most frequently associated with epidemics in Africa. More than one strain may be found at the same time within the same population [12] and carriage of multiple strains by the same person also occurs [14], with estimates of frequency varying from $6 \%$ to $35 \%$ in different studies [13-16]. Asymptomatic carriage can last from 30 days [12] to more than 10 months [15]. Numerous factors, including climate, virulence and susceptibility may be associated with the change from carriage to infection.

While the great majority of epidemics in the Sahel are caused by $N$. meningitidis serogroup A [6], epidemics are not always homogeneous. Infections with W135 were identified in a large outbreak in Ghana, though the majority of infections in the outbreak were due to serogroup A, suggesting that in some epidemics different strains may be circulating at the same time 
[17]. Epidemics of $N$. meningitidis serogroup $\mathrm{C}$ of variable severity have been recorded in a number of West African states such as Nigeria, Burkina Faso, Mali, Niger and elsewhere [1]. An 18-year follow-up in Niger showed that $N$. meningitidis A represented more than $85 \%$ of the strains isolated in Niamey before the emergence of serogroups $\mathrm{X}$ and W135 [18] and serogroup A remains the predominant isolate even in countries where other serogroups have been responsible for large epidemics $[19,20]$.

Sporadic cases or localized epidemics of $N$. meningitidis $\mathrm{X}$ have been reported in some countries, generally in inter-epidemic periods [21,22] while more recently, wider epidemics due to $N$. meningitidis $\mathrm{X}$ have been reported in Niger [20] and Northern Ghana [23].

In sub-Saharan Africa, the colonial expansion into the Sahel countries at the beginning of the 20th century, that introduced more effective diagnostic and reporting systems, revealed the severity of meningitis in the region. Meningococcal meningitis was diagnosed for the first time in Senegal at the end of the $19^{\text {th }}$ Century, and the first meningococcal epidemics were recorded two decades later in northern Nigeria and in French Niger. In the 1960s, Lapeyssonnie [24] made excellent observations on the epidemiology of $N$. meningitidis meningitis in sub-Saharan Africa and his conclusions are still used today. He specified the geographical limits of the epidemic areas and the climatic conditions favoring the recurrences; he described the African meningitis belt as an area of West Africa limited mainly by rainfall, being bound by isohyets with the northern limit set at $300 \mathrm{~mm}$ rainfall per year and a southern limit at an1100 mm rainfall (figure 2). Rainfall may not be the only factor, however, and the role of climate, rain, dryness, dust and wind in the epidemiology of meningococcal meningitis is now well established [2527]. It has been shown that epidemics begin after at least 5 consecutive days with dryness lower or equal to $30 \%$ [28], accounting for the seasonal occurrence of epidemics between February and May in most of the countries of the African meningitis belt.

As with asymptomatic carriage, the incidence of $N$. meningitidis meningitis has generally been considered to be influenced by age, being lower in children younger than two years and in adults older than 20 years $[24,28,29]$ However, in some studies the specific incidence of $N$. meningitidis was found to be similar in different age groups [30,31], whether during nonepidemic or epidemic periods. The detection of changes in the causes of infant meningitis, from infection with Haemophilus influenzae or Streptococcus pneumoniae to infection with meningococci, has been suggested in other regions as a good indicator of the start of a meningococcal meningitis epidemic [31] though this may not be reliable in the Sahel region.

Figure 2. African meningitis belt (according to [24]).

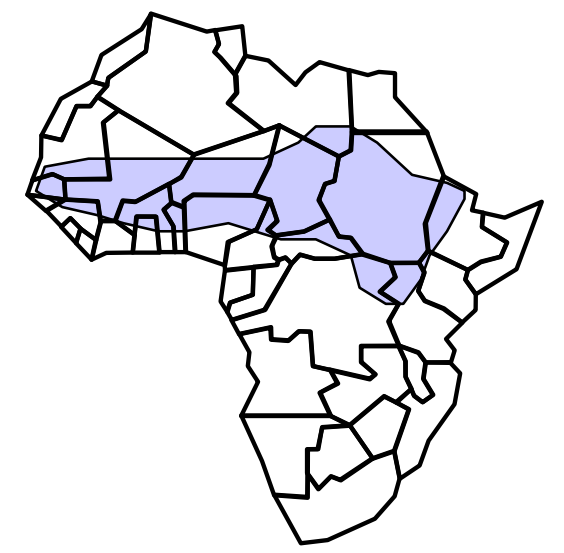

Epidemics generally occur every 5 to 10 years $[3,18,24,28]$ with relapses of epidemics occurring frequently one or two years after the first one in the same place and population $[18,32]$. The cycle of epidemics is irregular, though, and so far no reliable mathematical model can be used to predict epidemic occurrences [33]. On the other hand, the influence of the climate on epidemics is well known, and satellitebased climate observations may be a valuable source of data that could be used to anticipate the risk 3 to 6 months before epidemics occur [34]. Because environmental factors play such an important role in delimiting the at-risk zones, the organization of health services for controlling the anticipated epidemic can be put in place well in advance of the outbreak of disease [35].

Over the past thirty years, changes in the epidemiologic characteristics of the epidemics of $N$. meningitidis have been recorded, though some suggest this is a result of improvements in the monitoring system, better case reporting, more relevant descriptions of epidemics, and improvement in techniques of identification of the bacteria. Nevertheless, an apparent increase in the number of cases has been described in both rural and urban areas, possibly as a result of increased seasonal migrations associated with economic factors [36]. While such population changes may influence total numbers of cases, they do not explain changes in incidence, since these data take population size into account (figure 3). The extension of the African belt of meningitis is undoubtedly a more worrying phenomenon because it could represent the 
effects of climatic change and so may become a permanent feature in the region. Many epidemics have, since 1985, occurred outside the historical limits of the African meningitis belt [1,2,37-40]. This extension may occur as either a gradual extension of the margins of the conditions that support the spread of infection [39] or as outbreaks in areas far away from the region (such as Rwanda or Tanzania), which have had no previous history of such epidemics. While climate change, with progression of the desert, could explain the proximal extension [39], human migrations, such as the pilgrimage to Mecca, particularly during dry seasons, would be the most likely origin of the distal dissemination of infection [1]. Initially such infections may result in asymptomatic nasopharyngeal carriage, but potentially virulent bacteria may be introduced into an immunologically naïve population leading to outbreaks in areas where epidemics are previously unknown.

\section{Pathology}

As well as asymptomatic carriage, climate may also influence the passage through the mucous membrane into the blood-stream and the occurrence of disease. Environmental conditions such as dryness, wind and cold are important factors in the occurrence of African epidemics. As noted previously, bacterial genetic factors, particularly the molecular structure of the pili, are also important in determining whether bacteria can cross nasopharyngeal mucous membrane into the bloodstream [41]. In most cases after crossing the membrane, an asymptomatic bacteraemia usually occurs, and this may disappear spontaneously in few days. In some persons, in particular children not yet immunized, the bacteraemia may evolve to a more severe disease. In $20 \%$ to $30 \%$ of cases, septicemia may occur and this can lead to septic shock with severe hemorrhagic cutaneous symptoms (purpura fulminans) with a very poor prognosis. More frequently, however, after entering the blood-stream, bacteria cross the meningeal membranes to cause meningitis.

Case fatality rates in epidemics of meningitis in Africa have been generally recorded as $10 \%$ despite appropriate action being taken $[1,42,43]$; however, as noted previously, higher rates up to $50 \%$ may be experienced at the beginning of an epidemic. Neurological sequelae including deafness and mental retardation are common, occurring in more than $15 \%$ of the survivors $[43,44]$.
Figure 3. Incidence of meningitis in Niger between 1937 and 2000 showing the impact of scale changes (absolute number versus incidence (sources OCCGE and OMS).

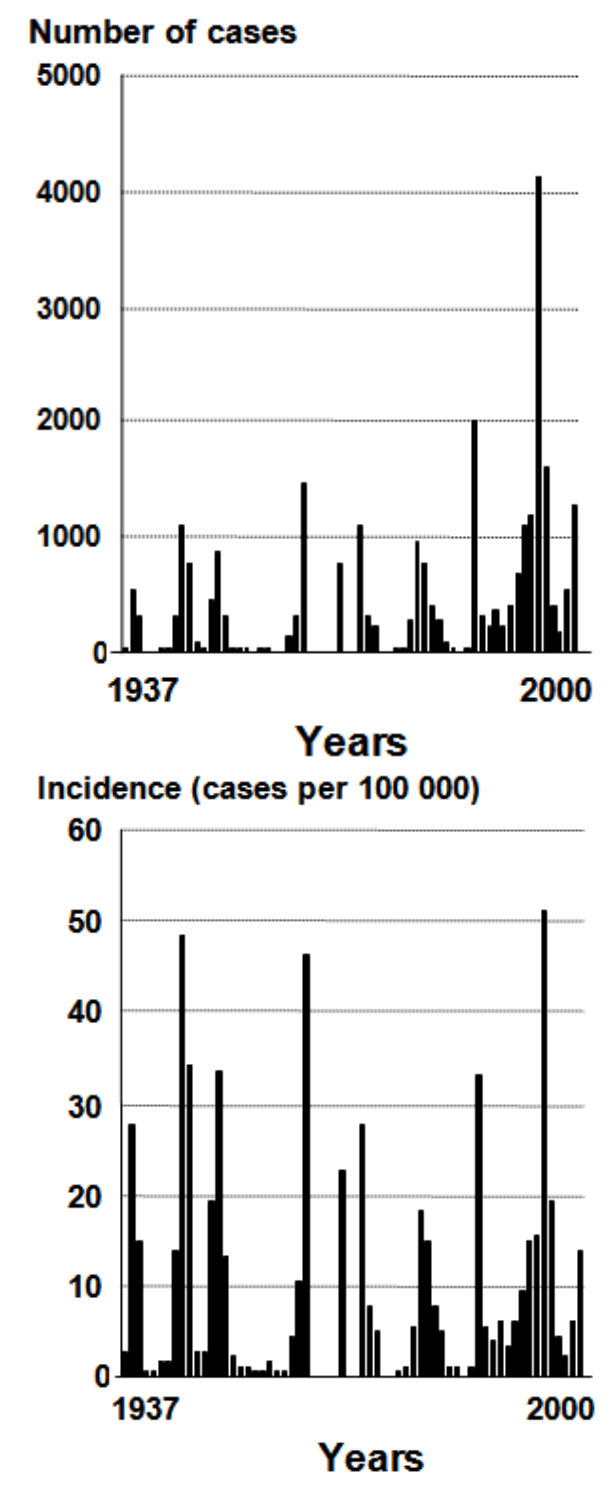

\section{Immunology and vaccines}

Neisseria meningitidis induces a humoral immune response with increasing titres of antibodies appearing about a week after contact with the antigen whether through infection or immunization [45,46]. Bactericidal antibodies are directed against capsular polysaccharides and the proteins of the outer membrane, and to a lesser extent against the lipopolysaccharides, and it is these antibodies that afford protection following immunization. Maternal IgG antibodies cross the placenta and protect infants during the first three months of life, following which infants acquire their own antibodies following either direct contact with bacteria or as a result of cross-immunity induced by 
saprophyte bacteria or bacteria closely related to $N$. meningitidis but with low virulence [10]. In countries belonging to the African meningitis belt, up to two thirds of adults have acquired bactericidal antibodies at a protective level [47]. The antibody titres vary in different populations with, in general, lower levels in countries with wetter climates, probably because of less frequent antigenic contact.

Because capsule polysaccharides are known to be important determinants of virulence that are also immunogenic, meningococcal polysaccharide vaccines (MPV) were the earliest candidate vaccines to be manufactured, with marketing of the first commercial vaccine providing protection against $N$. meningitidis A and $\mathrm{C}$ in 1976. The MPV has been shown to be very effective in people older than 4 years, well tolerated, and inexpensive $[48,49]$. The immune response is rather poor in younger children $[29,50]$ but in adolescents and adults, bactericidal antibodies are maintained for at least 5 years after vaccination [51]. Continued contact with natural antigens may contribute to persistence of protective antibody, since in North American populations protective antibodies are of much shorter duration [4].

Polysaccharide vaccines induce a T-cell independent response, theoretically without inducing the production of memory cells. This means that immune memory is of short duration, and periodic booster immunization is needed to give long-lasting protection $[52,53]$. The decline in protection is known to be age-related, being more rapid in younger $(<4$ years) than in older children [48]. Young children have poorly developed B-cell immunity, and the T-cell independent mechanism of responses to MPV may be the reason for this rapid decline in protective response.

These problems with MPV fuelled research into the development of protein antigen vaccines, since proteins induce a T-cell dependant response that is both effective from soon after birth and induces memory. Antibodies to meningococcal protein antigens alone were, however, not protective, and a strategy of coupling meningococcal polysaccharide antigens to immunogenic proteins from other bacteria was adopted. By covalent coupling to diphtheria or tetanus toxoid, the polysaccharides of $N$. meningitidis $\mathrm{A}$ and $\mathrm{C}$ acquire significantly improved immunogenicity. The meningococcal conjugate vaccine (MCV) was marketed at the end of 1990s, and was found to be well tolerated and induced long-lasting immunity even in young children and so, even though expensive, was considered to be more suitable for the control of meningitis in countries of the African meningitis belt [54,55]. Multivalent MCV vaccines, using a combination of A, $\mathrm{C}, \mathrm{Y}$, and $\mathrm{W}$ antigens, are under development. The overall conclusion of a number of trials has been that MCV gives greater and more durable protection than MPV, mainly because of the ability to induce memory. While theoretical considerations suggest that $\mathrm{MCV}$ would induce long-lasting immunity in endemic areas, there are no long-term data yet available [56].

Immune responses to different polysaccharide antigens are, however, complex. During a clinical trial in Niger, the immune responses of infants to polysaccharides $\mathrm{A}$ and $\mathrm{C}$ were determined following immunization with either MCV or MPV [54]. Following MCV vaccination, mean antibody titers against serogroup A polysaccharide were significantly higher than against serogroup $\mathrm{C}$ polysaccharide (figure 4). This was not the case in infants immunized with MPV where very similar levels of antibody were found against both $\mathrm{A}$ and $\mathrm{C}$ polysaccharides. Similarly with both polysaccharides, bactericidal antibodies $(>2 \mu \mathrm{g} / \mathrm{ml})$ were found in a greater proportion of infants following MCV vaccination than with MPV vaccination. Although mean antibody levels were similar among the MPV vaccinated infants, serum bactericidal titers against serogroup $\mathrm{C}$ were found in $70 \%$ of the infants, compared with only $31 \%$ who had serum bactericidal activity against serogroup A. When immunized infants were later exposed to MPV vaccine, as a marker of contact with meningococcal antigens, the response to either of the polysaccharides was greater in infants previously immunized with MCV (69\% to $92 \%$ with antibody levels $>2 \mu \mathrm{g} / \mathrm{ml}$ ) than those previously immunized with MPV (59\%). These data indicate that immune responses to the different vaccines vary more than at first thought, and more research is needed to give greater understanding of these responses. Clearly, though, MCV vaccines have greater potential for protection of children than do MPV vaccines.

The MCV has not been in widespread use for long enough to determine the duration of protection, but from a theoretical viewpoint, protection probably lasts longer than with the MPV [56]. However, in endemic areas, the lack of induction of memory by MPV may not be such a problem because populations are exposed to repeated infections with pathogenic or saprophytic Neisseria organisms, playing the role of "natural boosts" and reinforcing immunity [57].

Herd immunity, where protective mechanisms may spread quickly through a community in the absence of widespread clinical disease, is poorly understood in 
meningococcal meningitis though it may be a very important factor in the control of epidemics. Rhinopharyngeal carriage of $N$. meningitidis stimulates immune responses in mucous membranes, with production of locally active IgA in particular [57]. The impact of vaccines both on the production of mucous antibody and carriage of $N$. meningitidis has been examined, with generally a transitory increase in levels of specific salivary antibodies against the polysaccharides $\mathrm{A}$ and $\mathrm{C}$ following vaccination with MPV [57,58]. The MPV does not eliminate carriage of $N$. meningitidis though a reduction in the rate of contaminations occurring after its administration has been recorded [59]. It is probable, as for other conjugate vaccines [60] or the monovalent MCV prepared against $N$. meningitidis $\mathrm{C}[13,56]$, that the polyvalent $\mathrm{MCV}$ would have a significant impact on $N$. meningitidis carriage and thus on human-to-human transmission. Further studies are needed, however, to demonstrate the actual impact of large-scale immunizations with MCV on pharyngeal carriage, particularly with regard to the possible induction of capsule antigen mutations that may select for more virulent strains.

Figure 4. Compared immunogenicity of MPV and MCV in infants (according to [54]).

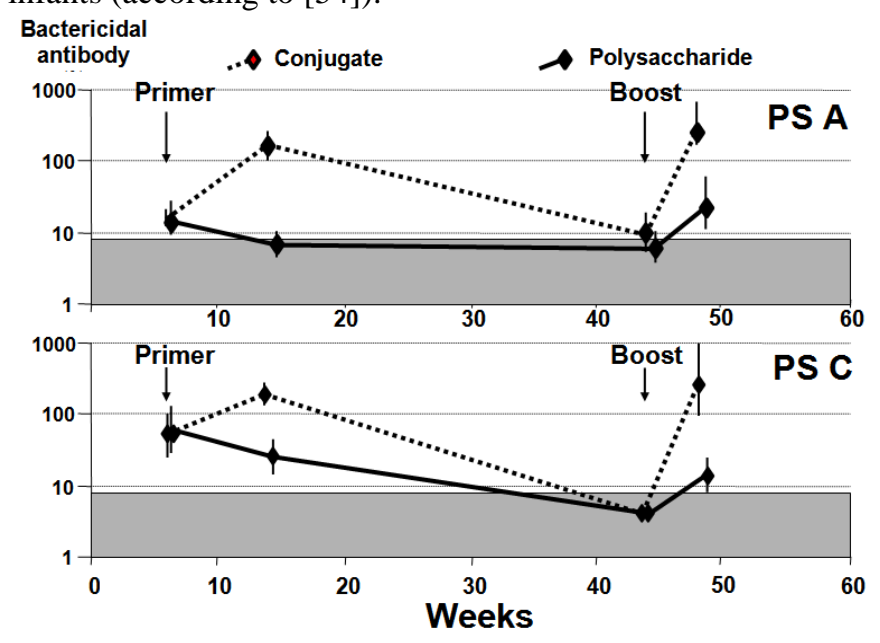

The significant decrease of meningitis incidence in non vaccinated people after a campaign of immunization supports the assumption of effective herd immunity even if the reasons remain largely unexplained [31,61-64]. Paradoxically, it has been suggested that increased vaccine coverage may result in an overall decrease in natural immunity at the population level. Because MPV induces only short-term immunity, failure to receive boosting antigenic stimulus by repeated exposure to bacteria means that immunity may be rapidly lost [65]. Moreover, the use of vaccines may stimulate changes in the epidemiology of carriage of different serogroups, though this may not necessarily influence the causes of meningitis [23]. During the meningococcal meningitis epidemic in Burkina Faso in 2003, protective antibody titers against $N$. meningitidis A were found in $54 \%$ of the population, which had received a MPV-A/C vaccine one year previously [16]. Nasopharyngeal swabs failed to detect carriage of group A serogroup, while $5 \%$ of the population carried $N$. meningitidis $\mathrm{W} 135$, and only $22 \%$ had protective antibody to this serogroup and then only of short duration and not associated with carriage. Despite the absence of carriage, serogroup A, rather than serogroup W135, was the major cause of meningitis in this region during this epidemic. The relationship between carriage, immunity, and disease is clearly one that is complex, and detailed studies are needed to fully understand how vaccination may impact on this relationship.

In general, vaccine coverage against $N$. meningitidis is very low in the meningitis belt of Africa [66] and is probably insufficient to interfere with natural immunity in populations in this region. The incidence of meningitis in the adult population has not undergone significant change, either increasing or decreasing, during the past 30 years when MPV vaccines have been available. We may conclude that natural immunity is preserved and not modified by immunization, at least with MPV vaccines.

\section{Control of epidemics}

It is well established that healthy carriers of $N$. meningitidis are more important for the dissemination of $N$. meningitidis than are patients $[1,36]$. Communitybased control measures have, therefore, been considered as of little value after the beginning of an outbreak [1], and greater attention has been paid to protection of persons in contact with patients once an epidemic has started. Prevention is primarily founded on two factors: a) environmental modification to limit the diffusion of the epidemic; and b) immunization of the persons at risk (those in contact with patients).

The environmental conditions conducive to both transmission and to the emergence of disease have been discussed above. While little can be done, at least at community level, to influence climate, many epidemics have been associated with specific behavioural practices. Frequent interpersonal contact has long been known to be a factor in transmission of infections. Social events which gather the rural African communities (markets, festivals, religious offices, funerals, baptisms, weddings or village meetings) may 
therefore be important factors in transmission [67]. There are, however, no intervention studies to show whether reducing the frequency of such gatherings during an epidemic can lead to significant reduction in transmission frequency sufficient to control or prevent epidemics. Greater reliance has therefore been given to immunization strategies.

There are two main strategies for immunizationreactive and preventive. Reactive immunization targets the at-risk population, according to age and outbreak proximity [29]. While this strategy is a priori easier to perform, immunization carried out during the epidemic is undoubtedly too late. This may be one reason that selective immunization campaigns, i.e. targeting a limited population, has had only limited success in control $[4,42,68]$.

Preventive immunization, given to populations before an epidemic begins through mass immunization campaigns in regions where epidemics occur, has been thought by many to be ineffective for three reasons:

a) the most widely-available vaccine, MPV, induces a poor immune response in children younger than 2 years $[29,48,50]$ and may even stimulate a defective immune response to some group specific antigens [69]

b) polysaccharide antigens do not induce a $\mathrm{T}$ dependant immunity, and so immunized children may be protected for only a short time $[48,52,53,70]$

c) the incidence of $N$. meningitidis is low in young children though rhinopharyngeal carriage may be prevalent $[24,28,29]$

Preventive immunization would therefore be expected to induce only weak and short-lived immunity that would be unable to prevent epidemics, and may even influence the normal immune responses to infection. The strategy currently recommended by WHO for controlling meningitis epidemics consists of early detection of clinical cases and reactive immunization of the people living in the epidemic area where an outbreak is confirmed $[1,71,72]$. The purpose of reactive immunization, however, is not to react to an ongoing epidemic but to reduce the spread of an epidemic when it is beginning. Such a strategy requires two things. On the one hand, the case detection and monitoring system must be sensitive and specific, so that the beginning of an epidemic is identified early, and so that true epidemics can be identified. It is essential to find an operational compromise between the specificity and the threshold of sensitivity of the epidemic to avoid an inappropriate implementation of the response by a too low specificity or a too great delay because of a lack of sensitivity [73]. The epidemic threshold that has been considered to be most appropriate (based, initially, on the analysis of an epidemic in Burkina Faso) is 15 cases per 100,000 inhabitants per week during two consecutive weeks $[1,5]$. The threshold has subsequently been revised as more data from different situations has been accumulated [73-76]. The reliability of epidemiological data, which depend on population size of communities, is an important factor in the reliability of threshold determination, and modern approaches introduce the concept of two levels of thresholds: alert and action. The alert threshold ( 5 cases per 100,000 inhabitants per week in communities of $>30,000$ inhabitants or 2 cases per 100,000 population per week in less populated communities) was defined to increase vigilance so that the response could be organized in a timely manner. The action threshold (set at 10 cases per 100,000 inhabitants a week in the cities of more than 30,000 inhabitants and 5 cases a week in the less populated communities) defined the time for reactive immunization [77].

It has been shown that the impact of reactive immunization was limited, leading to an approximately $30 \%$ reduction in numbers of expected cases even when carried out very early in the epidemic [78,79]. If introduced later, towards the end of the epidemic season, i.e. after the beginning of April, the impact of immunization may be confounded with the natural decrease of the epidemic [68]. The low effectiveness of this strategy convinced its promoters that it was also necessary to improve the organization of the vaccination campaigns to reduce as far as possible the delay between the beginning of the epidemic and the reaction. Organizational improvements, such as ensuring availability of security stocks of vaccines, establishing effective management teams, and the creation of internatonal coordination groups involved in evaluation of vaccines and logistic requirements have been recommended.

Despite all of these approaches, the annual incidence of the meningitis in sub-Saharan Africa remains dramatically high (table 1), and the late response to and inadequate management of the epidemics is regarded by many as the major reason for this. In contrast to the obvious failure of current strategies [80], the evidence from many epidemiologic studies have indicated that large-scale preventive immunization using MPV may well be effective $[4,42]$. Large-scale vaccination campaigns with MPV were organized in many Sahel countries, including Niger, Bénin, Egypt and Senegal [32,81-83]. In Senegal, the 
incidence of meningitis during the epidemic was two times lower in the villages that benefited from largescale vaccination two years before, than in the others [25]. This study also highlighted a significant link between the incidence and the vaccine coverage against meningitis.

Table 1. Suspected meningitis cases in Africa between 2001 and 2007 (sources WHO).

\begin{tabular}{|c|c|c|c|c|c|c|c|}
\hline Countries & 2001 & 2002 & 2003 & 2004 & 2005 & 2006 & 2007 \\
\hline Angola & 332 & - & - & - & - & - & - \\
\hline Benin & 7532 & 490 & 367 & 269 & 172 & - & - \\
\hline $\begin{array}{l}\text { Burkina } \\
\text { Faso }\end{array}$ & 10897 & 11899 & 7859 & 5296 & 2926 & 3636 & 22255 \\
\hline Burundi & - & 934 & - & - & - & - & - \\
\hline Cameroon & 415 & - & - & - & - & - & - \\
\hline $\begin{array}{l}\text { Central } \\
\text { African R. }\end{array}$ & 1816 & - & - & - & - & - & - \\
\hline Chad & 5780 & - & 614 & 863 & 1001 & - & - \\
\hline $\begin{array}{l}\text { Côte } \\
\text { d'Ivoire }\end{array}$ & - & 189 & - & 280 & 379 & 130 & - \\
\hline $\begin{array}{l}\text { Democratic } \\
\text { R. Congo }\end{array}$ & 378 & - & - & - & - & - & - \\
\hline Ethiopia & 5636 & 3540 & - & 2768 & 564 & - & - \\
\hline Gambia & 137 & 50 & - & - & - & - & - \\
\hline Ghana & - & 1407 & 1454 & 859 & 525 & - & - \\
\hline Guinea & - & 22 & - & - & - & - & - \\
\hline Kenya & - & - & - & - & - & 74 & - \\
\hline Mali & - & 336 & 868 & 906 & 326 & 160 & - \\
\hline Mauritania & - & 26 & - & - & - & - & - \\
\hline Niger & 4014 & 3518 & 8082 & 3483 & 1031 & 614 & - \\
\hline Nigeria & - & - & 3508 & - & 247 & - & - \\
\hline Rwanda & 164 & 636 & - & - & - & - & - \\
\hline Senegal & - & 71 & - & - & - & - & - \\
\hline Somalia & - & 237 & - & - & - & - & - \\
\hline Sudan & 2549 & 330 & - & - & - & 554 & 1129 \\
\hline Tanzania & - & 149 & - & - & - & - & - \\
\hline Togo & - & 559 & 313 & - & - & - & - \\
\hline Uganda & - & - & - & - & - & 551 & 241 \\
\hline
\end{tabular}

The first model to try to quantify the efficacy of different vaccine strategies was developed by Bovier [84] and was based on the results of data available from experience with the expanded program on immunization. These data indicated that the incidence of infectious diseases could be greatly reduced, even in areas where vaccine coverage was low. This model predicted that the two strategies would have similar effectiveness, preventing up to $60 \%$ of infections. The first opportunity to test whether such models could accurately predict experience came during an epidemic of meningitis in Ghana [85]. In practice, only $23 \%$ of the cases were prevented during this epidemic in spite of very favorable conditions: increasing surveillance due to the presence of meningitis epidemics in the nearest countries and mobilization of immunization teams thanks to large-scale vaccination campaigns for yellow fever at the same time [86]. Later experience in Senegal, however, showed that a large-scale vaccination carried out two years before an epidemic resulted in a $52 \%$ reduction in numbers of expected cases [32], a result close to that predicted by the Bovier model.

In addition to efficacy, the cost of the vaccine administration has to be taken into consideration, particularly in resource-poor settings such as those of the Sahel $[87,88]$. In the model developed by Miller [89], the long-term benefit that may be expected from a relatively expensive vaccine that had low efficacy and with a low vaccine coverage was assessed. In this situation reactive vaccination was shown to be more cost effective than preventive vaccination, a conclusion similar to that predicted from the Bovier model [84]. Only one "experimental" study has shown that preventive immunization is more cost-effective than reactive vaccination [90].

\section{Conclusion}

In the sub-Saharan countries, the epidemics of $N$. meningitidis meningitis continue to result in a high mortality in children younger than 15 years and even among the survivors, neurological sequelae are common. Expensive control measures have, until now, proved to be not very effective. The relative costefficacy of preventive vaccination (routine immunization of at-risk population to reduce the immunologic receptive population) compared with a reactive vaccination strategy, (vaccination of at-risk populations only in the event of a proven epidemic) remains one of the most controversial topics in meningitis prevention strategies $[4,42,80,86]$. The controversy will perhaps disappear when routine immunization with MCV becomes more generally available, because of the proven greater efficacy of $\mathrm{MCV}$ in stimulating long-term immunity in all age groups. While waiting for the arrival of the MCV, announced for most than a decade, the current data support the view that the MPV preventive-vaccination rather than reactive strategy is likely to be the most cost-effective approach to the control of meningitis epidemics.

As with other preventive vaccination strategies, such as EPI, it is necessary to introduce effective operational approaches exploiting the whole of the available resources including national days of 
immunization or medical action, institutional and associative relays, health system support, and open or school-based immunizations. It is known that the mothers are ready to mobilize themselves and take part in preventive immunization campaigns and even contribute financially to cost recovery [82]. However, when the strategy is adopted, it will be necessary to define the methods of application which must be both acceptable and relevant and evaluate the potential risk of meningococci serogroup selection.

\section{References}

1. WHO (1995) Lutte contre les épidémies de méningite à méningocoque. Guide pratique de l'OMS. Fondation Marcel Mérieux Ed, Lyon, France.

2. Hart CA, Cuevas LE (1997) Meningococcal disease in Africa. Ann Trop Med Parasitol 91:777-785.

3. Stephens DS, Greenwood B, Brandtzaeg P (2007) Epidemic meningitis, meningococcaemia, and Neisseria meningitidis. Lancet 369:2196-2210.

4. Chippaux JP, Debois H, Saliou P (2002) A critical review of control strategies against meningococcal meningitis epidemics in sub-Saharan African countries. Infection 30:216-224.

5. Moore PS, Plikaytis BD, Bolan GA, Oxtoby MJ, Yada A, Zoubga A, Reingold AL, Broome CV (1992) Detection of meningitis epidemics in Africa: a population-based analysis. Int J Epidemiol 21:155-162.

6. WHO (2007) Risk of epidemic meningitis in Africa: a cause for concern. Week Epidemiol Rec 82:79-87.

7. Kwara A, Adegbola RA, Corrah PT, Weber M, Achtman M, Morelli G, Caugant DA, Greenwood BM (1998) Meningitis caused by a serogroup W135 clone of the ET-37 complex of Neisseria meningitidis in West Africa. Trop Med Int Health 3:742-746.

8. WHO (2001) Meningococcal disease, serogroup W135 (update). Week Epidemiol Rec 76:157.

9. Blakesbrough IS, Greenwood BM, Whittle HC, Bradley AK, Gilles HM (1982) The epidemiology of infections due to Neisseria meningitidis and N. lactamica in a northern Nige-rian community. J Infect Dis 146:626-636.

10. Gold R, Goldschneider I, Lepow ML, Draper TF, Randolph M (1978) Carriage of Neisseria meningitidis and Neisseria lactamica in infants and children. J Infect Dis137:112-121.

11. Koumaré B, Konaté M, Cissé M, Doumbia T (1994) Etude du portage rhinopharyngé de Neisseria meningitidis sérogroupe $\mathrm{C}$ dans la collectivité autour des patients au Mali. A propos de 1033 sujets prélevés. Bull Soc Pathol Exot 87:148-151.

12. Mueller JE, Sangaré L, Njanpop-Lafourcade BM, Tarnagda Z, Traoré Y, Yaro S, Borrow R, Gessner BD, Nicolas P (2007) Molecular characteristics and epidemiology of meningococcal carriage, Burkina Faso, 2003. Emerg Infect Dis 13:847-854.

13. Leimkugel J, Hodgson A, Forgor AA, Pflüger V, Dangy JP, Smith T, Achtman M, Gagneux S, Pluschke G (2007) Clonal waves of Neisseria colonisation and disease in the African meningitis belt: eight- year longitudinal study in northern Ghan

14. Djibo S, Nicolas P, Campagne G, Chippaux JP (2004) Portage rhino-pharyngé de méningocoque $\mathrm{X}$ dans une école primaire de Niamey (Niger). Med Trop 64:363-366.

15. Boisier P, Nicolas $P$, Djibo S, Hamidou AA, Tenebray B, Borrow R, Chanteau S (2006) Carriage of Neisseria meningitidis serogroup W135 ST-2881. Emerg Infect Dis 12:1421-1423.

16. Mueller JE, Yaro S, Traore Y, Sangare L, Tarnagda Z, Njanpop-Lafourcade BM, Borrow R, Gessner BD (2006) Neisseria meningitidis serogroups $\mathrm{A}$ and $\mathrm{W}-135$ : carriage and immunity in Burkina Faso, 2003. J Infect Dis 193:812-820.

17. Forgor AA, Leimkugel J, Hodgson A, Bugri A, Dangy JP, Gagneux S, Smith T, Pluschke G (2005) Emergence of W135 meningococcal meningitis in Ghana. Trop Med Int Health 10:1229-1234.

18. Campagne G, Schuchat A, Djibo S, Ousséini A, Cissé L, Chippaux JP (1999) Epidemiology of bacterial meningitis in Niamey, Niger, 1981-96. Bull WHO 77:499-508.

19. Traoré Y, Njanpop-Lafourcade BM, Adjogble KL, Lourd M, Yaro S, Nacro B, Drabo A, Parent du Châtelet I, Mueller JE, Taha MK, Borrow R, Nicolas P, Alonso JM, Gessner BD (2006) The rise and fall of epidemic Neisseria meningitidis serogrou

20. Boisier P, Nicolas P, Djibo S, Taha MK, Jeanne I, Maïnassara HB, Tenebray B, Kairo KK, Giorgini D, Chanteau S (2007) Meningococcal meningitis: unprecedented incidence of serogroup X-related cases in 2006 in Niger. Clin Infect Dis $44: 65$

21. Djibo S, Nicolas P, Alonso JM, Djibo A, Couret D, Riou JY, Chippaux JP (2003) Outbreaks of serogroup X meningococcal meningitis in Niger 1995-2000. Trop Med Int Health 8:11181123.

22. Etienne J, Sperber G, Adamou A, Picq JJ (1990) Notes épidémiologiques : les méningites à méningocoques du sérogroupe X à Niamey (Niger). Méd Trop 50:227-229.

23. Gagneux SP, Hodgson A, Smith TA, Wirth T, Ehrhard I, Morelli G, Genton B, Binka FN, Achtman M, Pluschke G (2002) Prospective study of a serogroup $X$ Neisseria meningitidis outbreak in northern Ghana. J Infect Dis 185:618626.

24. Lapeysonnie L. (1963) La méningite cérébro-spinale en Afrique. Bull WHO 28:1-114.

25. Besancenot JP, Boko M, Oke PC (1997) Weather conditions and cerebrospinal meningitis in Benin (Gulf of Guinea, West Africa). Eur J Epidemiol 13:807-815.

26. Sultan B, Labadi K, Guégan JF, Janicot S (2005) Climate drives the meningitis epidemics onset in West Africa. PLoS Med 2:e6.

27. Mbaye I, Handschumacher P, Chippaux JP, Diallo A, Ndione JA, Paul P (2004) Influence du climat sur les épidémies de méningite à méningocoque à Niakhar (Sénégal) de 1998 à 2000 et recherché d'indicateurs opérationnels en santé publique.

28. Greenwood BM (1987) The epidemiology of acute bacterial menin-gitis in tropical Africa. In: Williams JD, Burnie J (Eds), Bacterial Meningitis, Academic Press, Londres, pp. 61-91.

29. Greenwood BM, Wali SS (1980) Control of meningococcal infection in the African meningitis belt by selective vaccination. Lancet i:729-732.

30. Campagne G, Chippaux JP, Djibo S, Issa O, Garba A 1999 Epidémiologie et contrôle des méningites bactériennes chez les nourrissons à Niamey. Bull Soc Pathol Exot 92:118-122.

31. Peltola H, Kataja JM, Mäkelä PH (1982) Shift in the age distribution of meningococcal disease as predictor of an epidemic? Lancet ii:595-597.

32. Chippaux JP, Diallo A, Marra A, Etard JF (2007) Impact of previous immunisation on the incidence of meningococcal disease during an outbreak in a Sahelian area of Senegal. Vaccine 25:1712-1718. 
33. Broutin H, Philippon S, Constantin de Magny G, Courel MF, Sultan B, Guégan JF (2007) Comparative study of meningitis dynamics across nine African countries: a global perspective. Int J Health Geogr 10:29-36.

34. Thomson MC, Molesworth AM, Djingarey MH, Yameogo KR, Belanger F, Cuevas LE (2006) Potential of environmental models to predict meningitis epidemics in Africa. Trop Med Int Health 11:781-788.

35. Molesworth AM, Cuevas LE, Connor SJ, Morse AP, Thomson MC (2003) Environmental risk and meningitis epidemics in Africa. Emerg Infect Dis 9:1287-1293.

36. Stephens DS (1999) Uncloaking the meningococcus: dynamics of carriage and disease. Lancet 353:941-942.

37. Luo N, Perera C, Holton J, Ayles H, Zumla A (1998) Spread of Neisseria meningitidis group A clone III-I meningitis epidemic into Zambia. J Infect 36:141-143.

38. Molesworth AM, Thomson MC, Connor SJ, Cresswell MP, Morse AP, Shears P, Hart CA, Cuevas LE (2002) Where is the meningitis belt? Defining an area at risk of epidemic meningitis in Africa. Trans R Soc Trop Med Hyg 96:242-249.

39. Savory EC, Cuevas LE, Yassin MA, Hart CA, Molesworth AM, Thomson MC (2006) Evaluation of the meningitis epidemics risk model in Africa. Epidemiol Infect 134:10471051.

40. Varaine F, Caugant DA, Riou JY, Kondé MK, Soga G, Nshimirimana D, Muhirwa G, Ott D, Hǿiby EA, Fermon F, Moren A (1997) Meningitis outbreaks and vaccination strategy. Trans R Soc Trop Med Hyg 91:3-7.

41. Nassif X, Beretti JL, Lowy J, Stenberg P, O'Gaora P, Pfeifer J, Normark S, So M (1994) Roles of pilin and PilC in adhesion of Neisseria meningitidis to human epithelial and endothelial cells. Proc Natl Acad Sci USA 91:3769-3773.

42. Robbins JB, Schneerson R, Gotschlich EC, Mohammed I, Nasidi A, Chippaux JP, Bernardino L, Maiga MA (2003) Meningococcal meningitis in sub-Saharan Africa: the case for mass and routine vaccination with available polysaccharide vaccines.

43. Hodgson A, Smith T, Gagneux S, Akumah I, Adjuik M, Pluschke G, Binka F, Genton B (2001) Survival and sequelae of meningococcal meningitis in Ghana. Int $\mathrm{J}$ Epidemiol 30:1440-1446.

44. Smith AW, Bradley AK, Wall RA, Mcpherson B, Secka A, Dunn DT, Greenwood BM (1988) Sequelae of epidemic meningococcal meningitis in Africa. Trans $\mathrm{R}$ Soc Trop Med Hyg 82:312-320.

45. Goldschneider I, Gotschlich EC, Artenstein MS (1969) Human immunity to the meningococcus. I. The role of antibodies. J Exp Med 129:1307-1326.

46. Goldschneider I, Gotschlich EC, Artenstein MS (1969) Human immunity to the meningococcus. II. Development of natural immunity. J Exp Med 129:1327-1348.

47. Amir J, Louie L, Granoff DM (2005) Naturally-acquired immunity to Neisseria meningitidis group A. Vaccine 23:977983.

48. Reingold AL, Broome CV, Hightower A, Ajello GW, Bolan GA, Adamsbaum C, Jones EE, Phillips C, Tiendrebeogo H, Yada A (1985) Age-specific differences in duration of clinical protection after vaccination with meningococcal poly

49. Saliou P, Stoeckel P, Lafaye A, Rey JL (1978) Essais contrôlés $\mathrm{du}$ vaccin anti-méningococcique polysaccharidique $\mathrm{A}$ en Afrique de l'Ouest Sahélienne (Haute Volta et Mali). Dev Biol Stand 41:97-108.
50. Greenwood BM, Bradley AK, Blakebrough IS, Whittle HC, Marshall TF De, Gilles HM (1980) The immune response to a meningococcal polysaccharide vaccine in an African village. Trans R Soc Trop Med Hyg 74:340-346.

51. Flitter BA, Ismail A, Vu D, Granoff DM (2007) Group A antibody persistence five years after meningococcal polysaccharide vaccination in the Sudan. Hum Vaccin 3:135139.

52. Ceesay SJ, Allen SJ, Menon A, Todd JE, Cham K, Carlone GM, Turner SH, Gheesling LL, DeWitt W, Plikaytis BD, Greenwood B (193) Decline in meningococcal antibody levels in African children 5 years after vaccination and the lack of an eff

53. Greenwood BM, Whittle HC, Bradley AK, Fayet MT, Gilles HM (1980) The duration of the antibody response to menin-gococcal vaccination in an African village. Trans $\mathrm{R}$ Soc Trop Med Hyg 74:756-760.

54. Campagne G, Garba A, Fabre P, Schuchat A, Ryall R, Boulanger D, Bybel M, Carlone G, Briantais P, Ivanoff B, Xerri B, Chippaux JP. Safety and immunogenicity of three doses of a Neisseria meningitidis $\mathrm{A}+\mathrm{C}$ diphtheria conjugate vaccine $\mathrm{i}$

55. Chippaux JP, Garba A, Ethevenaux C, Campagne G, de Chabalier F, Djibo S, Nicolas P, Ali H, Charrondière M, Ryall R, Bybel M, Schuchat A (2004) Immunogenicity, safety, and memory of different schedules of Neisseria meningitidis A/Cdiph

56. Girard MP, Preziosi MP, Aguado MT, Kieny MP (2006) A review of vaccine research and development: meningococcal disease. Vaccine 24:4692-4700.

57. Nieminen T, Kayhty H, Kantele A (1996) Circulating antibody secreting cells and humoral antibody response after parenteral immunization with a meningococcal polysaccharide vaccine. Scand. J Infect Dis 28:53-58.

58. Zhang Q, Choo S, Everard J, Jennings R, Finn A (2000) Mucosal immune responses to meningococcal group $\mathrm{C}$ conjugate and group $\mathrm{A}$ and $\mathrm{C}$ polysaccharide vaccines in adolescents. Infect Immun 68:2692-2697.

59. Greenwood BM, Hassan-King M, Whittle HC (1978) Prevention of secondary cases of meningococcal disease in household contacts by vaccination. Brit Med J 277:1317-1319.

60. Takala AK, Santosham M, Almeido-Hill J, Wolff M, Newcomer W, Reid R, Käyhty H, Esko E, Mäkelä PH (1993) Vaccination with Haemophilus influenzae type $b$ meningococcal protein conjugate vaccine reduces oropharyngeal carriage of $\mathrm{Ha}$

61. De Wals P, Dionne M, Douville-Fradet M, Boulianne N, Drapeau J, De Serres G (1996) Impact of a mass immunization campaign against serogroup $\mathrm{C}$ meningococcus in the Province of Quebec, Canada. Bull WHO 74:407-411.

62. Kriz P, Vlckova J, Bobak M (1995) Targeted vaccination with meningococcal polysaccharide vaccine in one district of the Czech Republic. Epidemiol Infect115:411-418.

63. Salleras L, Dominguez A, Prats G (1999) Control of serogroup $\mathrm{C}$ meningococcal meningitis by mass vaccination in Catalonia (Spain). Vaccine 17 Suppl 3:S56-S60.

64. Hassan-King MK, Wall RA, Greenwood BM (1998) Menin-gococcal carriage, meningococcal disease and vaccination. J Infect 16:55-59.

65. Higham JH (1997) Meningococcal vaccine in Sub Saharan Africa. Lancet 350:1707-1708.

66. Chippaux JP, Marra A, Diallo A, Simondon F, Etard JF (2006) Analyse de l'évolution de la couverture vaccinale à Niakhar, 
une zone rurale du Sénégal, entre 1984 et 2003. Bull Soc Pathol Exot 99:391-399.

67. Jahn A, Kudzala A, Kitundu H, Lyamuya E, Razum O (2001) Meningitis propagation in southern Tanzania: the role of a village video show. Trop Med Int Health 6:839-841.

68. Spiegel A, Greindl Y, Lippeveld T, Decam C, Granga D, Nahor N, Bordonado JL, Sperber G, Yankalbé M, Baudon D (1993) Effet de deux strategies de vaccination sur l'évolution de l'épidémie de méningite à méningocoque $\mathrm{A}$ survenue à N'Djamena (Tchad)

69. Gold R, Lepow ML, Goldschneider I, Gotschlich EC (1977) Immune response of human infants to polysaccharide vaccines of group A and C Neisseria meningitidis. J Infect Dis136:S31S35.

70. Poolman JT (1994) Nouveaux vaccins méningococciques. Ann Inst Pasteur Actualités 5:157-160.

71. Leake JA, Kone ML, Yada AA, Barry LF, Traore G, Ware A, Coulibaly T, Berthe A, Mambu Ma Disu H, Rosenstein NE, Plikaytis BD, Esteves K, Kawamata J, Wenger JD, Heymann DL, Perkins BA (2002) Early detection and response to meningococcal

72. Saliou P, Rey JL, Stoeckel P (1978) Une nouvelle stratégie de lutte contre les épidémies de méningites à méningocoques en Afrique Sahélienne. Bull Soc Pathol Exot 71:34-45.

73. Lewis R, Nathan N, Diarra L, Belanger F, Paquet C (2001) Timely detection of meningococcal meningitis epidemics in Africa. Lancet 358:287-293.

74. De Chabalier F, Hassane A, Chippaux JP (2000) Evaluation of surveillance thresholds for prediction of meningitis epidemics using ongoing surveillance data at the district level, in Niger. Trans R Soc Trop Med Hyg 94:251-252.

75. De Chabalier F, Djingarey MH, Hassane A, Chippaux JP (2000) Meningitis seasonal pattern in Africa and detection of epidemics: a retrospective study in Niger, 1990-98. Trans R Soc Trop Med Hyg 94:664-668.

76. Kaninda AV, Belanger F, Lewis R, Batchassi E, Aplogan A, Yakoua Y, Paquet C (2000) Effectiveness of incidence thresholds for detection and control of meningococcal meningitis epidemics in northern Togo. Int J Epidemiol 29:933940.

77. WHO (2000) Détecter une épidémie de méningite à méningocoque dans un pays à forte endémicité en Afrique. Recommandations de l'OMS. Week Epidemiol Rec 75:306309.

78. Lengeler C, Kessler W, Daugla D (1995) The 1990 meningococcal meningitis epidemic of Sarh (Chad): how useful was an earlier mass vaccination? Acta Trop 59:211-222.

79. Haelterman E, Boelaert M, Suetens C, Blok L, Henkens M, Toole MJ (1996) Impact of a mass vaccination campaign against a meningitis epidemic in a refugee camp. Trop Med Int Health 1:385-392.

80. Robbins JB, Towne DW, Gotschlich EC, Schneerson R (1997) "Love's labours lost": failure to implement mass vaccination against group A meningococcal meningitis in sub-Saharan Africa. Lancet 350:880-882.

81. Chippaux JP, Campagne G, Djibo S, Cissé L, Hassane A, Kanta I (1999) Preventive immunisation could reduce the risk of meningococcal epidemics in the African meningitis belt. Ann Trop Med Parasitol 93:505-510.

82. Hassan J, Massougbodji A, Chippaux JP, Massit B, Josse R (1998) Meningococcal immunisation and protection from epidemics. Lancet 352:407-408.
83. Nakhla I, Frenck RW Jr, Teleb NA, El Oun S, Sultan Y, Mansour H, Mahoney F (2005) The changing epidemiology of meningococcal meningitis after introduction of bivalent $\mathrm{A} / \mathrm{C}$ polysaccharide vaccine into school-based vaccination programs in

84. Bovier PA, Wyss K, Au HJ (1999) A cost-effectiveness analysis of vaccination strategies against $\mathrm{N}$. meningitidis meningitis in sub-Saharan African countries. Soc Sci Med 48:1205-1220.

85. Woods CW, Armstrong G, Sackey SO, Tetteh C, Bugri S, Perkins BA, Rosenstein NE (2000) Emergency vaccination against epidemic meningitis in Ghana: implications for the control of meningococcal disease in West Africa. Lancet $355: 30-33$

86. Obaro S (2000) Control of meningococcal disease in West Africa. Lancet 355:1184-1185.

87. Miller MA, Shahab CK (2005) Review of the cost effectiveness of immunisation strategies for the control of epidemic meningococcal meningitis. Pharmacoeconomics 23:333-343.

88. Kaninda AV, Varaine F, Henkens M, Paquet C (1997) Meningo-coccal vaccine in Sub-Saharan Africa. Lancet 350:1708.

89. Miller MA, Wenger J, Rosenstein N, Perkins B (1999) Evaluation of meningococcal meningitis vaccination strategies for the meningitis belt in Africa. Pediatr Infect Dis J 12:10511059.

90. Parent du Châtelet I, Gessner BD, Da Silva A (2001) Comparison of cost-effectiveness of preventive and reactive mass immunization campaigns against meningococcal meningitis in West Africa: a theoretical modelling analysis. Vaccine 19:3

Corresponding Author: Jean-Philippe Chippaux, IRD UR010, Team "Mother's and Child's health in tropical environment", Institut de Recherche pour le Développement, La Paz, Bolivia

E-mail: chippaux@ird.fr

Conflict of interest: No conflict of interest is declared. 